\title{
Why EMU is Irrelevant for the German Economy*
}

\author{
Adam Posen $^{* \star}$
}

June, 1998

\begin{abstract}
No one seems to be neutral about the effects of EMU on the German economy. Roughly speaking, there are two camps: those who see the euro as the advent of a newly open, large, and efficient regime which will lead to improvements in European and in particular in German competitiveness; those who see the euro as a weakening of the German commitment to price stability. From a broader macroeconomic perspective, however, it is clear that EMU is unlikely to cause directly any meaningful change either for the better in Standort Deutschland or for the worse in the German price stability. There is ample evidence that changes in monetary regimes (so long as non leaving hyperinflation) induce little changes in real economic structures such as labor or financial markets. Regional asymmetries of the sorts in the EU do not tend to translate into monetary differences. Most importantly, there is no good reason to believe that the ECB will behave any differently than the Bundesbank.
\end{abstract}

Keywords: EMU, central bank, monetary policy, Germany

JEL classification: E5, F3

\footnotetext{
Presented at the CFS-Forum, Center for Financial Studies, Frankfurt, June 18, 1998. I am grateful to the Center and especially to Prof. Dr. Gerhard Illing for their hospitality and support. The views expressed in this paper are solely my own, and not those of the CFS, the Institute for International Economics, or any members of their staffs.

** Institute for International Economics, 11 Dupont Circle, N.W., Washington DC 20036-1207, USA, Tel. +1 (202) 328-9000, Fax: +1 (202) 328-5432, E-mail: aposen@iie.com
} 
It is a privilege to be addressing this audience on the subject of Germany's next great change in monetary regime at the time of the fiftieth anniversary of the reform, which gave the world the deutsche mark. Discussions of European monetary unification and the replacement of the DM with the euro take on a special meaning in this context. Even though the euro's arrival is now, thankfully, a foregone conclusion, many Germans still discuss the matter with some urgency. Roughly speaking, there are two camps: those who see the euro as the advent of a newly open, large, and efficient regime which will lead to improvements in European and in particular German economic competitiveness; and those who see the euro as a weakening of the commitment to price stability upon which the German Wirschaftswunder was based. I would like to offer an outside perspective from an American monetary economist, albeit one who has spent much of his professional life concerned with German monetary policy and what might be learned from its success. EMU is unlikely to cause directly any meaningful change either for the better in Standort Deutschland or for the worse in German price stability. In short, EMU is irrelevant for the German Economy.

Let me clear that I have consciously chosen each word of my title. "Irrelevant" meaning that there will be no influence, not that on net, the beneficial and the harmful cancel each other out; "German" meaning that my remarks apply to the leading and largest economy in the European Union, and not to some countries of the periphery for whom EMU will make some real difference (although probably not as much as some prophesize); "Economy" meaning the performance of the macroeconomic aggregates of the German economy (growth, inflation, unemployment), and not the deep political significance of EMU either for German foreign policy or for domestic discussions of German national identity. In fact, through the political channel either europhoria or europhobia could have great consequences, economic and otherwise. My point today is that if people look at the effects of monetary regimes analytically and comparatively there is little economic justification for getting excited about Germany's membership in EMU either way.

Coming to this assessment requires an examination of three sets of implications for EMU. First is the question of whether changes in monetary regimes induce changes in real economic structures, such as labor market institutions or depth of financial markets. The general point is that there is ample evidence that economic structures are actually quite 
resistant to change, and so the believers in euro-bred increases in competitiveness will be disappointed. Second is the question of whether differences among member economies in the European Union, or at least in the euro-zone, are so great as to require dangerous monetary policy accommodations. Here the lesson to be learnt is that regional differences very rarely translate into monetary policy moves, and the underlying asymmetries are in any event exaggerated, and so the euro-skeptics have little to fear. Third is the question of whether the European Central Bank will behave differently from the Bundesbank in such a way as to allow if not promote rises in inflation. On this concern, I am particularly certain that such fears are misplaced for a host of reasons. Ultimately, the reason EMU is irrelevant for the German economy is the same reason that the currency reform of 1948 succeeded: the underlying stability and support of civil society for responsible economic policies. For this reason, the only danger which can come from EMU arises if the European Central Bank neglects its responsibility and its self-interest in building political legitimacy for its work.

\section{Why Europhoria is misplaced: Structures are Solid -}

There are two primary reasons why inflation is a bad thing, generally speaking ${ }^{1}$. First, it redistributes income without consent, from creditors to debtors, fixed income to flexibly compensated, private-sector to government. Second, inflation interferes with the proper allocation of goods in markets by harming the information flows; inflation raises uncertainty about long-term planning, and confusions about nominal versus real pricing, especially with regards to the tax system and to financial markets. The first concern of redistribution, however, is one which only begins to matter when inflation rates reach higher levels, certainly in excess of $10 \%$ annual rate, probably not until $20 \%$ or $30 \%$ is reached ${ }^{2}$. It is the second concern that drives most opposition to inflation by monetary

\footnotetext{
1 Two excellent summaries of the literature on the costs of inflation which go into more detailed classifications than the one given here are Stanley Fischer (1981), "Towards an Understanding of the Costs of Inflation:II , Carnegie-Rochester Conference Series on Public Policy, 15, and Clive Briault (1995), "The Costs of Inflation," Bank of England Quarterly Bulletin, 33.

2 Interestingly, there is mounting evidence from cross-national growth regressions that inflation only imposes measurable real costs at a similar threshold, i.e. when inflation reaches double-digit levels. See Michael Sarel (1995) "Nonlinear Effects of Inflation on Economic Growth," IMF Staff Papers, 43, and Robert Barro (1995), "Inflation and Economic Growth," Bank of England Quarterly Review, 35.
} 
policymakers in the industrialized democracies. ${ }^{3}$. The oft-expressed hope by central bankers is that if a state of price-stability were to be reached - a situation in which "the general level of prices is not a factor in household and business decisions," in the famous phrase of Alan Greenspan -then wages and prices would be more flexible both up and down, and relative to each other. Without fear of inflation, it would appear that there is no reason for this not to happen.

Whether or not they realize it, most claims for Europhoria are based on this hope that wider area of price stability leads to better information leads to more efficient and flexible allocation of resources. When we are all sick of hearing about "Eurosclerosis", there is a certain ring to this. The problem with such a hope is that it assumes that too much of the structure of markets which we all face is driven by information problems, and that those information problems are largely attributable to government actions. This, it goes almost without saying, is a faith highly consistent with the optimality of free markets. The empirical evidence, however, is that market structures are actually the result of economic and political interests for the most part, and even to the extent that information imperfections support them, the removal of uncertainty about the price level does not knock out that support. In other words, both links in the causal chain from price stability to information to efficiency are of doubtful relevance once one is dealing with stable economies with low inflation rates. I will illustrate this point with evidence from labor markets, product markets, and financial markets, which I think pretty much covers it.

On labor markets, the entire history of the European economy for the last twenty years can be looked upon as an exercise in proving that wage-setting is largely unresponsive to variation in monetary regimes. Ideally, where there is lower inflation - or in most of today's models equivalently greater credibility of commitment by the central bank to price stability - workers should be less subject to money-wage illusion, more cognizant of the need to demand wage increases in line with productivity gains, more willing to recontract when relative prices for their services and products shift, and so on. Of course, nothing of the sort is the case. For many perfectly rational reasons having nothing to do with monetary

\footnotetext{
3 The absence of a long-run "Phillips Curve" trade-off between inflation and output removes the one argument for why a policymaker acting in the public interest would want to engage in trend inflation when an economy is at or close to full employment. See the discussion in Frederic Mishkin and Adam Posen " (1997), Inflation Targeting: Lessons from Four Countries," Federal Reserve Bank of New York Economic Policy Review, August.
} 
stability, workers do demand non-zero wage increases even when real wages have risen in pursuit of fairness and status ${ }^{4}$, unions do demand wage rises out of line with the associated change in productivity ${ }^{5}$, and sticky nominal contracting does persist even where central banks have long been independent and kept inflation low ${ }^{6}$. One need only look at German postwar economic history to see evidence of such behavior even in the face of long-standing price stability. The experience of German monetary unification only underlines this fact, where despite the Bundesbank successfully and credibly maintaining price stability in the face of volatile money demand and an unpredicably sized demand shock, wage-setting in the Neuen Bundeslaender displayed all three of these inflexible and inefficient behaviors ${ }^{7}$. It is entirely irrelevant for purposes of today's discussion whether the blame for such results rests with political influence by the Kohl government, or a self-interested power grab by western German workers at the expense of their eastern counterparts, or even with the many compensating benefits of the wage-setting sytem in Germany as part of a larger corporatist system (which, I to some degree believe in) - what is relevant is that fifty years of price stability in Germany has not produced wage flexibility.

This point cannot be limited to some special argument about Germany. Switzerland and the United States, the two major economies with records of price stability comparable to Germany's join Germany at the top of the OECD rankings in nominal wage rigidity and in sacrifice ratios even controlling for that rigidity ${ }^{8}$. The idea of a sacrifice ratio, the amount of output foregone or earlier of workers made unemployed to achieve a point drop in the rate of inflation ${ }^{9}$, is important because it highlights the idea that even where disinflation is known to be likely, it remains costly. There is some value to the stickiness of nominal

\footnotetext{
${ }^{4}$ See the discussion in George Akerlof, William Dickens, and George Perry, (1996)"'The Macroeconomics of Low Inflation," Brookings Papers on Economic Activity, 1.

${ }^{5}$ There is a vast literature on this topic and the incentives for so doing. A seminal contribution is Assar Lindbeck and Dennis Snower, (1984), The Insider-Outsider Theory of Unemployment.

${ }^{6}$ I established this result in a working paper in 1994 which is forthcoming as Adam Posen, "Central Bank Independence and Disinflationary Credibility: A Missing Link?", (1998), Oxford Economic Papers, 50, July. See also Guy Debelle and Stanley Fischer (1994), "How Independent Should A Central Bank Be?", in Federal Reserve Bank of Boston Conference volume.

7 A brief history of German monetary policy during this period is given in Thomas Laubach and Adam Posen, "Disciplined Discretion: Monetary Targeting in Germany and Switzerland," (1997), Princeton Essays in International Finance, no. 206.

8 Posen (1998), op cit.

${ }^{9}$ Most current literature refers to the method of measuring sacrifice ratios based on the Hodrik-Prescott filter developed in Lawrence Ball, (1996), "What Determines the Sacrifice Ratio?", in N. Gregory Mankiw, ed., Monetary Policy. (University of Chicago Pres)
} 
contracting which outweighs even very substantial losses. ${ }^{10}$ Changes in monetary regimes have offered natural experiments testing this hypothesis. In Canada, the central bank made an explicit commitment to price stability in 1988, and followed this with the announcement of a numerical inflation target in 1991, and justified both moves with reference to the likely benefits for labor and product market flexibility ${ }^{11}$. While the Bank of Canada wisely and soberly acknowledged that it did not expect to see rapid adjustment of labor markets and wage setting practices, it is now more than seven years of historical lows for Canadian inflation later, price stability having been maintained through a disinflation, an election, a referendum on Quebecois sovereignty, and many movements in the US/Canadian exchange rate, and the labor markets in Canada still display significant inflexibility and unemployment.

Similar stories can be told about other countries which made sustained and, by measures of inflation expectations, credible commitments to price stability, such as New Zealand adopting inflation targeting, Spain adhering to the ERM and the Maastricht criteria, and Argentina adopting a currency board, only to find no improvement in labor market flexibility. Again, the point is not that there might not be good reason for this inflexibility to persist, or that structural reform would be incapable of improving matters. What is important is that changes in monetary regimes have not induced changes in the structures of labor markets. No matter what one thinks about the credibility of the European Central Bank's commitment to price stability - and I, for one, think it will be quite high, as I argue below - it is difficult to imagine that a new central bank about which so much doubt exists will succeed in inducing such change where all these other central banks have failed. People who want to enhance European competitiveness by increasing labor flexibility will not get it from EMU.

What about product markets? We hear a great deal in the press about how "price transparency" will increase competitive pressures and thereby increase efficiency in the eurozone. Even for an economist quite willing to believe in ad hoc assumptions about the limitations of people's information gathering abilities, such as myself, this stretches credulity. It is all well and good to point out that even McDonald's "Big Mac" sandwiches

\footnotetext{
10 In addition to the stories told about reasons for nominal wage stickiness given in preceding footnotes, there are reasons given for price stickiness in the "New Keynesian" literature. See Lawrence Ball, N. Gregory Mankiw, and David Romer, (1986), "The New Keynesian Macroeconomics and the OutputInflation Tradeoff," Brookings Papers on Economic Activity, 1.

${ }^{11}$ See Mishkin and Posen (1997), and the references to the statements and publications by Bank of Canada officials during this time period therein, for a history of this regime shift.
} 
vary in home currency price across european borders right now. Very few items which are purchased, however, are individual hamburgers. Anyone dealing in more than a dozen of a non-perishable item can find it worthwhile to ascertain the original price, take out their pocket calculator (or perhaps given the better math's training in European than American schools, can do it in their head) and multiply the price by the local exchange rate. The German consumer who knows every specification on the new Mercedes M-Class can surely pick up this additional number.

More importantly, the vast bulk of the economy consists of trade between businesses at the wholesale level. There are economies of scale to making foreign exchange conversions - it is the same two numbers to multiply whether I am buying one Mercedes or a full shipment of them - and many financial and business consultants who would only be too happy to be paid to do this for a business, so there is no way this cannot be costefficient to pursue. If individual consumers do not bother to find out the conversion, there is something other than lack of transparent price information causing them to curtail their purchase decision-making process, and that will persist even after the euro's introduction. At the other end of the scale, when engaged in longer-term, multiple-unit, contracts across borders, there is something called foreign exchange hedging, which while not without cost or residual risk, does take care of most of the problem - and again there are only too many financial advisors and firms happy to aid businesses in surmounting this information problem $^{12}$. The idea that business to business transactions are pervaded by a lack of "price transparency" makes no sense whatsoever.

The "price transparency" idea rests on an even faultier premise than that of euroaffected costs of acquiring the information: the idea that most products are commodities which are purchased solely on the basis of price. Whether one reads Schumpeter on entrepreneurs avoiding competition, Michael Porter on competitive advantage, or the current business press on the success of "branding," one recognizes that profits come from monopoly power (actually, any good microeconomics textbook will demonstrate this). The

\footnotetext{
${ }^{12}$ It should be noted that one advantage of EMU often held out is the removal of foreign exchange risk and conversion costs. This benefit should not be exaggerated - if these costs, especially post-advent of derivatives markets, were terribly high, we would not have seen the growth in world trade we have seen since hedging was introduced; moreover, part of the costs of these hedges are revenues accruing to financial firms, which will then lose this market within euroland. No responsible observer puts the net benefits of removing such costs at more than a one-time gain of a few-tenths of a percent of GDP, and even that may be exaggerated.
} 
primary pursuit of business is the development of a patent, or a brand name, or a market niche, or a relationship with customers, and so on, all of which are ways of generating rents rather than having to price to market. The whole tradition of German Handwerk writ large, from building machine tools to customer specifications, to high-end luxury automobiles, to relationship banking, is premised on the idea that one adds value, or is perceived to, and then is paid for it. Jack Welch, the well-known CEO of General Electric, has been quoted several times recently claiming that today his firm "has no pricing power," as part of the discussion of the so-called "New Economy" in the United States. Within the single currency United States as well as in world markets, however, there is vanishingly little evidence of a decline in pricing power, or of the absence of price differentials between markets ${ }^{13}$. Mr. Welch is also famous for stating and carrying through that his company will not remain in any business where it is not the number one or the number two player, which by definition means that he wants GE only in businesses in which there are identifiable players competing with economies of scale, i.e.not on the basis of price alone.

While "Big Macs" may differ in price across euroland, Coca-Cola costs almost exactly the same per liter everywhere - which shows the unimportance of price transparency because the only reason brown sugar water costs as much per liter as petrol is that there is a brand identification. Much cheaper drinks, transparently labelled not only in price but in ingredients and health benefits, do not compete with Coke except at the margins.. In a time of rapid technological change, the principle of monopoly rents is even stronger, because research and development costs are extremely high, yet production costs are very low, so one has only a temporary monopoly which one attempts to extend through the creation of product standards, services and incompatibilities, and brand loyalties ${ }^{14}$. A far greater share of the industrial democracies' goods and services are these sorts of goods, both at the consumer and at the wholesale business level than are "Big Macs". Those goods which are true commodities, such as petrol, wheat, butter, low-end wine, and so on, are transparently priced where they are not already either denominated in one currency or regulated in price

\footnotetext{
13 One can also visit my current place of residence, Washington, D.C., and experience wide variation in supermarket prices along a ten mile drive, despite the ample availability of price information in advertisements in a single language.

${ }^{14}$ Raymond Vernon developed thinking along these lines in the concept of the"product cycle" many years ago, where first-world companies produce high-value added products with secret or patented components, and when the secret or patent runs out, production is moved off-shore if not sold-off completely. See Raymond Vernon (1973), Sovereignty at Bay, Cambridge:Harvard University Press.
} 
by government. In summary, if euro is to bring efficiency and competition through price transparency, it is bucking an insurmountable tide of business organization and of developments in tastes and technologies.

So will financial markets be the means through which the creation of the euro will change the German economy for the better? There is no question that German financial markets are under pressure to be more efficient, and that an appropriate change in this regard could have significant beneficial effects ${ }^{15}$. The question is whether the euro itself is the source of this pressure for change, and even if not, whether it will accelerate the process. The answer to the first is clearly not, and the answer to the second is not in any significant way without conscious help. The basic uncompetitiveness of the relationship banking system, like that of the similarly premised Japanese Main Bank system, may still be open to question in the minds of some (particularly in this audience), but the evidence is in $^{16}$. Rather than argue that point today, let us say instead that if one believes that German financial markets will be subjected to competitive pressures, they will be from New York and London and various electronic sites, and not from the ability of Germans to now drive past the Deutsche Bank filiale in Luxembourg all the way to Credit Lyonnais in Paris.

Besides, was there not something already passed by the EU called the "Investment Services Directive"? Large companies who get their accounting in order (and even some not so large ones) can tap capital markets directly already. As with the "pricing transparency" issue, it is clear that the benefits of getting one's capital as cheaply as possible are so large, and the availability of financial firms providing information on the price of their services is so ample, that the euro cannot make any difference on the demand side of corporate finance. A similar argument can be made on the demand-side of individual savers - had German savers ever truly been motivated by rate of return considerations, their bank accounts would have been emptied for superior investments long ago. To whatever extent

\footnotetext{
${ }^{15}$ I suggest that financial market efficiency has kept the U.S. economy afloat and could make up for labormarket inefficiencies in Germany in Adam Posen (1998), "Agreement without Convergence: Some Guidelines for Transatlantic Economic Relations" Remarks given on the Economics Panel Conference on "What Should We Do for the Relationship with America?", Social Democratic Party of Germany, Berlin, Germany ,January 1998.

16 See Adam Posen (1997), "Beyond Japan's Fear of Finance," mimeo, Institute for International Economics, May and the references there in. In particular, Robert Chirinko and Julie Ann Elston (1996), "Finance, Control, and Profitability: An Education of German Bank Influence", Mimeo, Wissenschaftszentrum Berlin fuer Sozialforschung, May, documents the negative correlation between Hausbank relationships and firm profitability. The recent moves of Daimler-Benz, SAP, and other German companies, to American arms-length financing show a revealed preference.
} 
German savers are waking up to the idea that they should get a market return on their investments, that an Aktienkultur is awakening, it is driven by forces beyond the euro, such as the privatization of Telekom and the obvious differences from American experiences.

So if there is no demand-pull from the euro dragging the German financial system into greater efficiency, is there supply push? That is, even if the euro is not the source of the pressure on German finance, might it not accelerate the process by making European finance more competitive? While the euro might contribute to a spirit of excitement in this city of Frankfurt, and might give the banks an opportunity to promote brand loyalty by instructing clueless depositors at length in advertisements, presentations, and publications about the complications of the euro, the arguments for direct benefits are meagre ${ }^{17}$. As summarized excellently in an IMF report, the financial effects of the eurozone depend critically upon the development of the market in government debt instruments ${ }^{18}$. While the euro certainly does not hinder such development, it is also not sufficient for it; in the United States it took active work by the Federal Reserve in the form of both regulations and monetary policy operating procedures to create a liquid and securitized market. To the extent that the European Central Bank strictly follows a narrow mandate of price stability without active regard for financial stability (something implied by clear price stability mandate and the absence of direct remarks to this effect in Article 105(1) of the Maastricht Treaty), such a market may not emerge. A minimum reserve based system will also tend to limit central bank participation in the markets because of the lack of need to stabilize the overnight funds market. It is not even clear that the euro is necessary to such an endeavor since the French financial system has made strides towards creating a deep and liquid government debt market even while existing in a world of intra-european exchange rates.

Even without that sort of liquid government debt market, it is always possible that the creation of the eurozone will somehow lead to greater economies of scale in other forms of finance, say in the issuance of corporate debt. Two true changes which do occur as a result of the euro's introduction is the elimination of the "anchoring principle," which

\footnotetext{
17 This is akin to the current boom in the U.S. for every company with a possible tie to information technology, from computer firms to business consultants to training schools, telling all their customers that they will help them get ready for the internet. While this builds loyalty to the offering firm, presumably, it remains unclear what "getting ready for the internet" either entails or implies for their customers.

18 Alessandro Prati and Garry Schinasi, (1997) "European Monetary Union and International Capital Markets: Structural Implications and Risks," in EMU and the International Monetary System. (IMF)
} 
requires domestic financial institutions to lead-manage bond issues, and the elimination of the 80 percent matching rule on foreign currency exposures of pension funds and insurance companies. Yet with regard to the first, it is not clear that the removal of a competitive protection will lead to advantages for the formerly protected domestic industry - the far more experienced handlers of bonds and securities in London and New York may simply grab market share. With regard to the second, this will be offset now by an added need to diversify since so much of the portfolio becomes denominated in one currency. As already mentioned, whatever gains the traded goods sectors of the economy make from removal of some currency risk, is also the eurozone financial sector's loss of demand for a product.

Whether considering wage-setting, product markets, or even financial services, it is doubtful that the introduction of the euro will bring about beneficial change. The inflexibilities and information imperfections that exist in the structures of these markets are based on far more solid factors than monetary regimes and price stability alone can dislodge.

\section{Why Europhobia is Misplaced (I): Asymmetries are overrated -}

Having established why the coming of the euro is unlikely to be particularly good for the German economy, I would now like to turn to why it is unlikely to be particularly bad for the German economy either ${ }^{19}$. Much of the discussion of EMU in the 1990s has revolved around the themes of whether the eurozone consitutes an optimal currency area, and of whether the differences in initial debt positions of the countries participating are consistent with low inflation. Usually, by comparison to the United States, Europe actually looks rather good on the first criterion; the distinction between debt levels and the issuance of new debt calms the nerves on the second point. Yet, never has so little data been mined by so many to so little avail. The Europhobe looks at the Mediterranean EU members, sees high debt levels and very different economies, as well as perceived histories of fiscal and monetary irresponsibility, and fears that trouble is inevitable. Either these economies will renege on their commitments to price stability once in the eurozone, or they will run into shocks and cycles far different from those in the core countries and therefore demand different policies, or they will free-ride upon the credibility of Germany and the euro to issue grand new amounts of debt - or perhaps all three within weeks of joining. In any

\footnotetext{
19 In keeping with my title, this section leaves aside the question of whether there might not be some political gains that would be worth even a sustained small rise in inflation, were one to occur.
} 
event, the result foreseen is that Germany suffers from greater inflation having joined EMU with the current membership than it would have had it stayed out.

As with the Europhoria position with regards to competition, this point of view is actually premised on a three part chain of events: eurozone members differing significantly in preferences leading to European Central Bank governors voting differently which leads to inflation. There are significant problems with the first link, that between asymmetries in the eurozone and central bank votes. First, however, I would like to raise some questions about the initial assumption that eurozone members have widely differing preferences ${ }^{20}$. Economists are taught to be forward-looking, which does not necessarily mean to discard all past information when making a prediction, but which does mean to be a bit careful in deciding which aspects of the past are relevant to forecasting the future. Thus, the characterization of members on the basis of past performance requires some care.

Suffice it to say that countries' long-run average inflation rates are not terribly indicative of anything. For one thing, it is frequently those countries who suffered the most from past price stability which have the greatest support for it. Not only should this sound familiar on the fiftieth anniversary of the deutsche mark, but from the various stabilizations undertaken in Argentina, Chile, Israel, and elsewhere in recent years. Of course, for every Argentina there is a Brazil (which may be making a change before our eyes), so one cannot argue that hyperinflation predicts future price stability, but there is certainly no clear association running the other way. The second thing to be noted in this regard is that not all eras are the same. While German monetary policymakers may well deserve great credit for having discerned that price stability should be the primary goal of monetary policy some decades ahead of most of the rest of the world's central banks, that simply says we can understand why the Banca d'Italia, for example, may have chosen (or been forced to follow) a different set of priorities in the 1970s. Moreover, when one merely has moderate inflation, say between $10-30 \%$ annually, one is almost certainly better off reducing it gradually, as opposed to under hyperinflationary conditions where the costs of waiting and the benefits of shock treatments are both higher ${ }^{21}$. The fact that these EMU member countries' high inflation levels persisted for some time after their original policy mistakes of the 1970s

\footnotetext{
${ }^{20}$ Remember, we are discussing the central bank chiefs of these countries, not the median voters.

21 For a discussion of the differences of macroeconomic policy implications of the differing levels of levels of inflation, see Rudiger Dornbusch and Stanley Fischer (1994), "Moderate Inflation's," World Bank Economic Review.
} 
(typical of that time) merely reflects prudent policies, not a continuing failure to understand the importance of price stability. There is no question that in 1998 there are no central bankers in Europe, and very few politicians with any hope of attaining national power, who do not believe as the Bundesbank believes now.

It also strikes one, or at least me, a bit odd to dismiss preferences which are current and have been revealed at some cost. I refer, of course, to the sizable budget cuts, disinflations, and accompanying rises in unemployment which were undertaken by the eurozone members in their pursuit of the Maastricht eligibility criteria for EMU membership. One could state that these are sunk costs, and thus irrelevent to future decisions. I believe that assertion is false, however, and that, as opposed to past inflation levels, these past policy decisions are true indicators of the depth of the eurozone members' commitment to the project including price stability. Sunk cost arguments do not play very well in politics, especially since voters are rationally retrospective, that is using past performance to evaluate political candidates ${ }^{22}$. No politician or politically motivated central banker, can say, "we paid all that to get into EMU, and guess what, our inflation and interest rates are going back up!” The only way this makes sense as a rational strategy would be for a new candidate or party to run on an anti-euro ticket at some later date. Such a prediction misconstrues the fact that politics is a continual process, ongoing even between elections. On the one hand, if this euro-opposition were a viable strategy, it could have been supported at any time prior to EMU, when the costs were being incurred and the benefits (such as lower rates) only partially felt. Moreover, there is no reason not to think that over a multi-year period of highly visible policies, the policies do not reflect the wishes of effective political coalitions (whether majorities or not) within these nations.

On the other hand, once a country enters the eurozone, the costs of its defection (either having its central banker vote for inflationary policies or actually withdrawing or attempting to alter the underlying system) rise enormously. Thought of as a one-shot game, a country might have an incentive to enter the eurozone and then run deficits in so far as possible, but it is not playing a one shot-game. It would be visibly reneging on a long-term commitment with its closest economic and political allies, defecting in a manner transparent

\footnotetext{
${ }^{22}$ There is a vast political economy literature establishing this fact both theoretically and empirically. Fiorina, Morris (1981), Retrospective Voting in American National Elections. New Haven, CT: Yale University Press. Rogoff, Kenneth (1990), "Equilibrium Political Budget Cycles," American Economic Review 80:21-36
} 
to all markets. Since we do expect that in the eurozone the emphasis on credit rating will shift to risks other than currency, such tendencies will hardly go unnoticed ${ }^{23}$. There are many other reasons as well to doubt that prior debt standing, or even debt issuance, will lead to problems for ECB monetary policy. Given the size of international capital markets and the easier evaluation of credit risk without exchange risk added on, it is very difficult for any one country's borrowing behavior to influence other member states' interest rates or behavior. In turn, this makes bond issuers' ability to force a monetary policy change on other members quite limited; this also reduces the incentives to engage in such debt-creating behavior versus when the central bank is responsive to your government alone. ${ }^{24}$ For another point, the likelihood of default or rapid creation of debt heading in that direction is a decreasing function of a country's tax base ${ }^{25}$, and all the euro member states have solidified that to the extent they did not already have a sizable one in place in their efforts to meet the Maastricht criteria.

So the asymmetric preferences argument for why the membership of the eurozone will fail to support price stability, either due to past inflationary proclivities or to past debt levels, turns out to be itself difficult to support. The next question then is whether a shock could come which would be sufficiently asymmetric to cause monetary policy to work against price stability and German interests. Rather than rehash the data about the relative synchronization of business cycles in the eurozone, I would like to make to more conceptual points about monetary policymaking in this regard. The first is that price stability is itself a means to an end, where that end is higher economic welfare of a country's or an economic and political union's citizens. What this means is that although price stability is the appropriate long-run goal for monetary policy, in any given short-run there may be good reason for monetary policy to diverge from this goal, and, if properly managed, this

\footnotetext{
23 See Prati and Schinasi, op cit, and Daniel Gros, (1998) "EMU and Capital Markets", IfK-CFS Working Paper for discussion of the credit rating issue. Also, whether rational or not, it is well established that markets punish defaulting countries with interest rate premia long after the event takes place, and any reneging within the eurozone will engender a similar response.

24 See the discussion in Paul de Grauwe (1996), "Reforming the Transition to EMU", in Peter Kenen, ed., "Making EMU Happen Problems and Proposals: A Symposium," Princeton Essays in International Finance, No. 199.

${ }^{25}$ This result is documented in Barry Eichengreen and Juergen von Hagen, (1995), "Fiscal Policy and Monetary Union: Federalism, Fiscal Restrictions, and the No-bailout Rule," CEPR Discussion Paper No. 1247.
} 
divergence need not do damage to inflation expectations ${ }^{26}$. In fact, a monetary policymaker which does not react to offset severe or persistent real shocks in the short-run may damage his counterinflationary credibility in the long-run since the markets and citizens know there are limits to what should be sustained ${ }^{27}$.

The point of this for the future European Central Bank is that it is difficult to imagine a shock to the part of the eurozone that is both sufficiently large that the region affected's central bank(s) will want to loosen, but that such loosening will not also be in Germany or the core's interest as well. Remember, the starting point of EMU was economic intergration, and the members of the eurozone are those nations which have the most cross-border economic ties. If there were to be a major banking crisis in France and Belgium, or a natural disaster hitting the agriculture of the Iberian peninsula, it would be in German interests to cope with such a supply shock be easing policy whether or not the euro exists simply because these economies are integrated with the German economy on the real side. Failure to loosen would bring wide swings in trade, in movement of workers, and in capital flows, as well as recessionary forces, to Germany regardless of whether Germany would be in or out of EMU. Moreover, it enhances a central bank's credibility to loosen in response to a supply shock thereby distinguishing it in the public's mind from a demand shock or another source of inflation.

Turning to my second point, I want to establish that it will require a shock over a rather high threshold to prompt a divergence in voting patterns, so the only likely pressures for ease will come when it is in Germany's best interests in any event. There is a wellestablished theoretical literature on how committees function, as well as good historical evidence on the behavior of central bank boards. Both rational incentives (e.g. the power of the Chairman to set the agenda) and cultural traditions (e.g. the Becket effect) militate towards consensus and away from initiatives from non-central members of the committee. The most powerful example is that of the U.S. Federal Open Market Committee. As you are aware, the Fed's decision making body consists of the Chairman and Board of

\footnotetext{
${ }^{26}$ This argument is developed at length, especially in Chapters 1, 2, and 11, of Ben Bernanke, Thomas Laubach, Frederic Mishkin, and Adam Posen, (1998) Inflation Targeting: Lessons from the International Experience, Princeton University Press, forthcoming.

${ }^{27}$ Allen Drazen and Paul Masson, (1994)"Credibility of Policymakers versus Credibility of Policies," Quarterly Journal of Economics, makes a formal argument for this point. Laubach and Posen, op cit, provides several examples of such behavior in the German and Swiss monetary experience since Bretton Woods.
} 
Governors, the President of the New York Federal Reserve Bank, and four of the remaining twelve reserve bank members who get to vote at any time. What you may not know is that each Federal Reserve District is required to prepare before every FOMC meeting, whether or not it can vote, a so-called "Beige Book." This report consists of data and appraisal of the economic situation in that Federal Reserve District. Not only are these Beige Books prepared and made publicly available, the every FOMC meeting starts by going around the table having each Reserve Bank President report on conditions in their District.

Despite the fact that such a structure would seem to militate strongly for Reserve Bank Presidents to"vote-their-districts", i.e., for their votes to reflect their public statements about unemployment and growth in their region, there is no evidence that they do so ${ }^{28}$. Of cousre, the analogy between Federal Reserve Districts within the U.S. and national central banks within Europe is far from perfect. Yet, economic policy in the United States in many other areas is strongly driven by regional or state concerns, even where there is much less institutionalized public identification of the policymakers with their constituencies - and there are no proposals on the table for the European Central Bank to engage in any public discussion of regional developments anywhere close to that undertaken by the FOMC. Meanwhile, the asymmetries of business cycles and unemployment between regions in the U.S. and nations in Euroland are at a minimum comparable, if not worse in the United States.

Europhobia resting on the differences amongst the membership of the EMU member economies is not well grounded. Given the lack of asymmetries of preferences from those of the Bundesbank I have discussed, some very strong assumptions about politics in the eurozone are required to make the case that the European Central Bank will loosen policy in ways that the Bundesbank would not. I turn to that now.

\section{Why Europhobia is Misplaced (II): Central banks are largelythe same -}

Having spent the bulk of my professional career and before that my graduate training on the study of comparative monetary policies and central bank practices, I am loathe to let you in on the key secret of that research: in the OECD today, almost all central banks

\footnotetext{
${ }^{28}$ One recent study looking at this question and finding no evidence for such regional preferences is Ellen Meade and Nathan Sheets (1998), presented at the AICGS Hoenmans Program Panel on "The European Central Bank: How Accountable? How Decentralized? Lessons from the Bundesbank and the Federal Reserve System," May 22, Washington.
} 
behave in the same way. In fact, if one were to take out 1973-1982 in the OECD economies, and a couple of hyperinflations in the developing world, one could say that most central banks have behaved much like the Bundesbank for most of the postwar era. Remember, membership in the Bretton Woods fixed exchange rate system, and the necessary efforts to maintain parity within it, just like membership in the European ERM after it, and in the gold standard before it, was a matter of choice by governments - there was no deus ex machina preventing these countries from devaluing and/or leaving the system $^{29}$. Throughout the 1980s and 1990s, inflation rates have been dropping worldwide, even in those countries not tied to explicit exchange rate commitments, even though disinflation remains a costly process, and even though central banks retain the power to create inflation $^{30}$. If one were to argue that it was the international environment of freemoving capital and lack of economic shocks which brought about this downward trend, that is fine, but then one cannot be terribly concerned about the European Central Bank being loose with policy since it would be subject to the same forces.

I would argue instead that this trend represents an overwhelming consensus of central banks on what monetary policy can and cannot do. One way of seeing this is look at the numerous papers estimating central bank reaction functions, or on the closely related fitting of "Taylor rules" to various central banks' interest rate policies, or those comparative histories of monetary policy which do exist ${ }^{31}$. On the one hand, subject to the prudent desire for gradual disinflation I discussed above, all central banks have a long-run goal of practical price stability, meaning a measured inflation rate on the order of 2-3\%; all inflation targeting and monetary targeting regimes in the OECD explicitly set that as their goal, as we document in Bernanke, Laubach, Mishkin, and Posen (1998), and even those central bank without such transparent regimes either reveal that preference (e.g.,United States, Japan), or accept that as a goal by pegging their exchange rates to a country which does announce that goal (e.g., France, Ireland). On the other, even the supposedly "hard"

\footnotetext{
${ }^{29}$ For a discussion of the gold standard in line with this interpretation, see Michael Bordo and Hugh Rockoff (1995), "The Gold Standard as a 'Good Housekeeping Seal of Approval"”, NBER Working Paper No. 5340

${ }^{30}$ This latter threat being the justification for the enormous academic literature on the time-inconsistency of monetary policy, from Kydland, Finn E. and Prescott, Edward C. (1977), "Rules Rather Than Discretion: The Inconsistency of Optimal Plans" Journal of Political Economy and Calvo, Guillermo A., (1978), "On the Time Consistency of Optimal Policy in a Monetary Economy" Econometrica, onwards.
}

${ }^{31}$ A recent paper featuring the first two of these approaches and results is Clarida, Gali, Gertler (1997). 
counter-inflationary central banks do display consistent concern for sharp short-run shocks to the real economy, exchange rates, and to financial stability ${ }^{32}$. Even the Bundesbank accomodated the second oil shock and worried when the DM grew too strong too quickly; even the Banque de France has attained interest rates for French government debt at times lower than that of German debt. The stylized division of central banks into those which care relatively more about unemployment than inflation, and vice versa, may be a useful modelling exercise, but there is little evidence of it in central bank behavior.

Another way of seeing this is to simply talk to the central bankers themselves, or read their interviews and speeches - as was remarked frequently during the discussion of the appointment of the ECB president, the statements of Duisenberg, Tietmeyer, and Trichet, and even the Finnish candidate, were largely interchangeable. It is, of course, possible to see these as statements solely for show, but it is very difficult in theory or in practice (with watching financial markets) to conceive of a disinformation campaign by central bankers which could be successfully sustained, and if not sustained, rapidly punished. The existence of an academic literature arguing that some central banks will

\footnotetext{
32 See Bernanke, Ben and Mishkin, Frederic. (1992), "Central Bank Behavior and the Strategy of Monetary Policy: Observations from Six Industrialized Countries" in NBER macroeconomics annual 1992. Laubach and Posen (1997), and Mishkin and Posen (1997) for historical examples of this behavior. Of course, the significance of the growth or unemployment variables, and lately of interest-rate smoothing concerns, in Taylor-rule type regressions is also consistent with this point.
} 
want to hide their "soft" type should be taken as an existence proof or a warning that such behavior might occur ${ }^{33}$ - it is not a proof that all statements cannot be taken seriously, especially those repeated at length over time. As Bennett McCallum observed with respect to the time-inconsistency problem of monetary policy, central banks can simply "choose not to play that game."34

Of course, the Europhobe states that the problem is not the intents of the central bankers, but the pressure which national governments and politics will put on them ${ }^{35}$. This statement is an act of particularly strong doubt - as I've noted above, the countries were if anything subject to more pressure and less cost to giving in to it during the run-up to EMU than after EMU itself. Still, the fact that the possibility of an exchange rate adjustment is removed is seen as the factor which will tip an already disgruntled domestic politics into outright revolt. This doubt, however, rests on two assumptions: that the ECB can indeed be influenced by short-run political influences; and that the politics are such that this lack of exchange flexibility will overload people's toleration. The Europhobes are misguided on both counts.

On the matter of whether or not central banks respond to short-term political pressures, the evidence is clear. Despite the press and academic attention given to the possibility of political-business cycles and the like, the only OECD country which has good evidence of a political monetary cycle (i.e., monetary policy varying with the timing and results of elections) is Germany, and clearly this has not harmed price stability ${ }^{36}$. In fact, there is no evidence of any correlation, negative or positive, between the existence of political monetary cycles and the independence of central banks, even leaving the German

\footnotetext{
${ }^{33}$ The paper beginning this literature is that of Cukierman, Alex and Meltzer, Allan-H, (1986), "A theory of Ambiguity, credibility, and Inflation under Discretion and Asymmetric Information". Econometrica.

34 Bennett McCallum, (1995), "Two Fallacies Concerning Central Bank Independence," American Economic Association Papers and Proceedings, May

${ }^{35}$ Rationally, claims that the markets rather than the average German citizen will find much to doubt about the euro have largely vanished. The markets saw the basic similarity of central banks long before the academics recognized it. There are also several contextual and fundamental reasons why the euro should begin life as a strong currency; for a partial list, see C. Fred Bergsten, (1997) "The Dollar and the Euro," Foreign Affairs, July/August.

${ }^{36}$ See Susanne Lohmann (1998), " Federalism and Central Bank Independence: The Politics of German Monetary Policy, 1957-92" World Politics, 50:3 and Alesina, Alberto, Nouriel Roubini, and Cohen, Gerald, (1992), "Macroeconomic Policy and Elections in OECD Democracies" in Political economy, growth, and business cycles. Cambridge and London: MIT Press.
} 
case out of $i^{37}$. Thus, in order for electoral politics to undermine the ECB's price stability, the politicians will have to somehow be more effective in exerting leverage over their central bank representatives on the ECB board than they ever were on their own national boards - this despite the fact that they presumably have less leverage over those Maastrichttreaty protected visitors to Brussels and they will be getting less payoff since they will be swaying only one vote (perhaps two if the Council members are somehow subject to such pressure). And even if such political pressure manages to sway one or even two votes, it would then have to be timed such that several more voters at the ECB were subject to contemporaneous pressure for this to matter at all to actual monetary policy outcomes. The odds of that happening are very low, especially without it arising from a very wide ranging or severe shock in the eurozone, which, as I've argued, it makes sense for the ECB to accomodate in any event.

Central bank independence is actually a much simpler and less powerful concept than many have made it out to be. While there are famous charts showing a negative correlation between various indices of legal measures of insulation of the central bank from politics $^{38}$ - such as the term of office of the governor or the prohibition of government representatives from serving on the board -there is really only one aspect that matters. It is not the one people usually think of. For example, much has been made of the ECB's mandate being if possible even more focussed than the Bundesbank's on price stability and only price stability. As I show in Figure 1, however, there is no correlation between a central bank's legal mandate and its average inflation performance, something which should not be surprising since the Schweizerische National Bank and the U.S. Federal Reserve would both score below 0.6 on this score, and yet produced performance similar to that of the Bundesbank ${ }^{39}$. One can make a similar statistical test for almost every other aspect of

\footnotetext{
${ }^{37}$ See Adam Posen (1998), "Central Bank Independence and Disinflationary Credibility: A Missing Link?", op cit.

${ }^{38}$ Cukierman,Alex , Webb,Steven B. and Neyapti, Bilin, (1992) "Measuring the Independence of Central Banks and It's Effects on Policy Outcomes" World Bank Economic Review and Alesina, Alberto and Summers Lawrence H. (1993), " Central Bank Independence and Macroeconomic Performance: Some Comparative Evidence", Journal of Money, Credit and Banking.

${ }^{39}$ Figure 1 plots the average inflation rates versus a score computed by Cukierman,Alex (1992), Central Bank Strategy, Credibility, and Independence: Theory and Evidence, Cambridge and London: MIT Press for the mandate of the central bank, where "price stability only" gets a 1, "price stability first but not only" gets a 0.8 , and so on down to "potentially inflationary goal(s), with no mention of price stability" getting a 0 score. The result is robust to inclusion of non-OECD countries and to different years of average inflation than those presented.
} 
central bank independence, and produce a similar lack of correlation. The explicit legal prohibition of central banks printing money to finance government deficits does matter - a scatterplot would show two clusters of countries, where those with such a prohibition have low inflation, and those without have higher rates of inflation. The European Central Bank, in addition to clearly having this legal protection, has far greater practical barriers to the monetization of deficits than any national central bank simply because it is subject to many authorities, each with their own separate debt or (in the case of the Board members) none at all. There is no mechanism, let alone incentive, for any one member country's debt issuance to be funded by printing money; monetization of all members' debt issuance at once would be self-defeating as a disastrous obvious signal to markets, punished immediately by eurodepreciation and interest rate rises.

So what are the politics which the European Central Bank should fear? To my mind, it is those of the radicals, the unemployed, the opportunists of left and right - in essence, those who have a tendency not to fear the ECB being too soft, but to believe it being illegitimate or too tough. The europhobe side of the debate in Germany has focussed on the Omas, your grandparents on pension who think "currency reform ->inflation->bad" and "Bundesbank -> monetary targeting ->good." This focus has two negative effects: it pushes the ECB into copying the Bundesbank's form even when it does not necessarily have the same capabilities and face the same challenges ${ }^{40}$; it distracts attention from the need for the ECB to err on the side of transparency and accountability so as to minimize the risk of reaction. The Omas are no threat to anyone - they will not take to the streets of Frankfurt in protest; they will not pull their money out of the eurozone if they cannot be bothered to move it out of their Sparkassen for higher returns; they will not even influence domestic politics, for if they had such weight Germany would have had a referendum or no EMU accession at all. The reasons for Europhobia that so many Germans address are those of an impotent group.

For those spurred to action or opportunism by perceptions of a democratic deficit for the ECB, this is another matter entirely. It may be there is nothing which the European Central Bank can do to prevent such radicalism, or it may be that the radicalism will never become politically meaningful, especially given good monetary policy performance (which is 
likely). Nonetheless, this means that the future risks of the policies of the European Central Bank being politicized actually depend on the Bank's support in the society at large. That is why the birth of the deutsche mark in 1948 and the transition to the euro fifty years later ultimately are both examples of the irrelevance of monetary regimes over the long-run. The deutsche mark was a success, bringing price stability and confidence to Germany, because at that time German civil society was itself prepared to support stability and market outcomes, and because the Bundesbank made the right call on a number of difficult policy decisions over the years which could have eroded that support. I have argued that the Bundesbank in fact consciously engaged in efforts at transparency and accountability far in excess of its legal requirements, and independent of its short-run policy peformance precisely because of its recognition of this fact ${ }^{41}$. Beyond the German example, I have shown that countries have gotten the central banks and the price stability for which they had the effective political opposition to inflation to support. ${ }^{42}$

While EMU is irrelevant for the German economy, someone, preferably the European Central Bank and the Bundesbank representative to it, should make sure that every German citizen understands this fact. Feel free to use this talk as text, and tell their citizens that they deserve the credit for price stability in Germany over the long-run. It is up to them to assure the same for the eurozone. EMU neither helps nor harms them in that pursuit.

\footnotetext{
${ }^{40}$ See Adam Posen (1998), "No Monetary Masquerades for the ECB," presented at the AICGS Hoenmans Program Panel on "The European Central Bank: How Accountable? How Decentralized? Lessons from the Bundesbank and the Federal Reserve System," May 22, Washington.

${ }^{41}$ See Adam Posen (1997), "Lessons from the Bundesbank on the Occasion of its $40^{\text {th }}$ (and second to last?) Birthday," Institute for International Economics Working Paper 97-4, March.

${ }^{42}$ See Adam Posen (1993), "Why Central Bank Independence Does Not Cause Low Inflation: There is no Institutional Fix for Politics," in Richard O'Brien, ed., Finance and the International Economy: 7 (Oxford University Press) and (1995), "Declarations are not Enough: Financial Sector Sources of Central Bank Independence," NBER Macroeconomics Annual 1995 (MIT Press).
} 
Figure 1

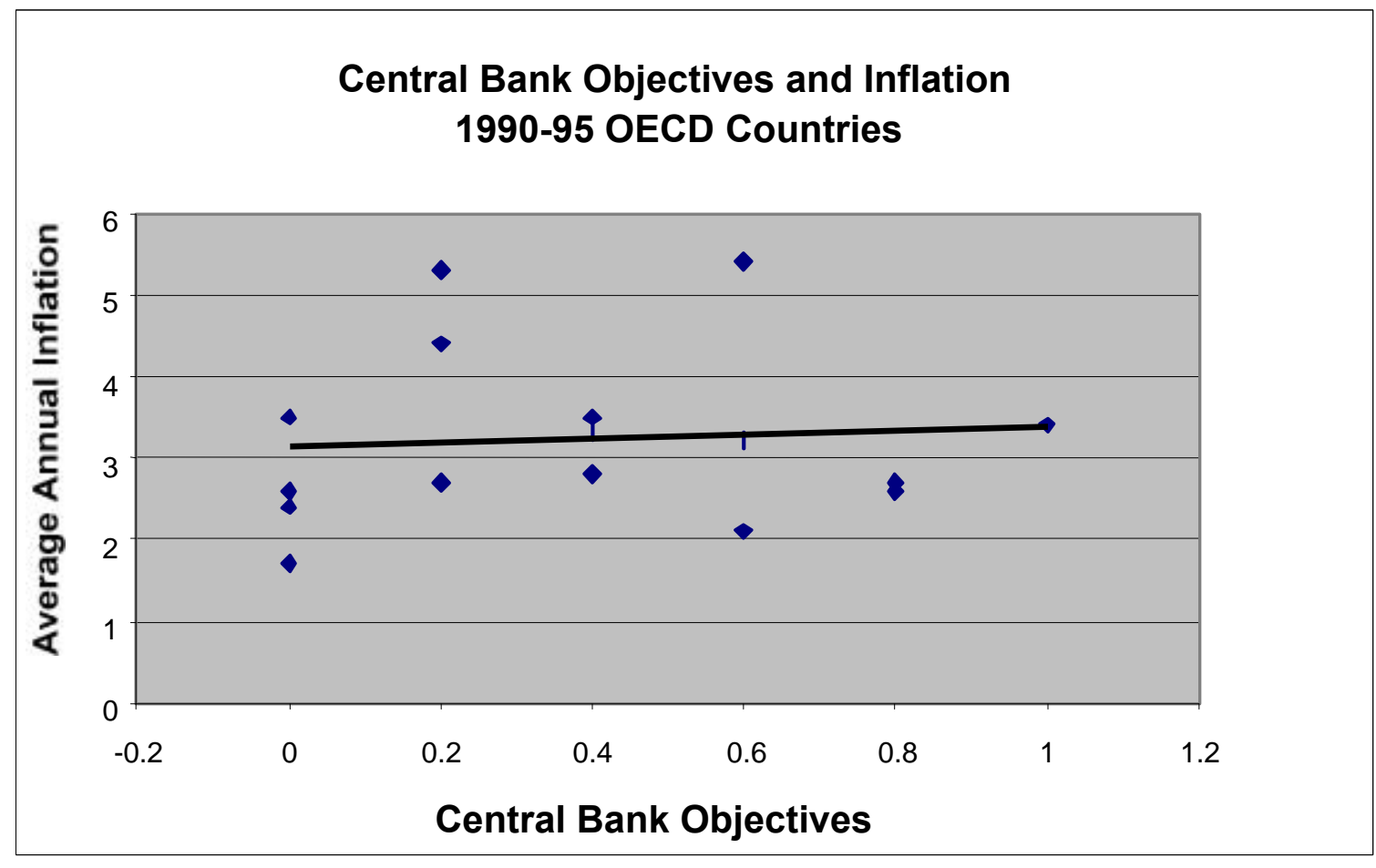

$$
\begin{aligned}
& y=0.2472 x+3.1292 \\
& R 2=0.0058
\end{aligned}
$$

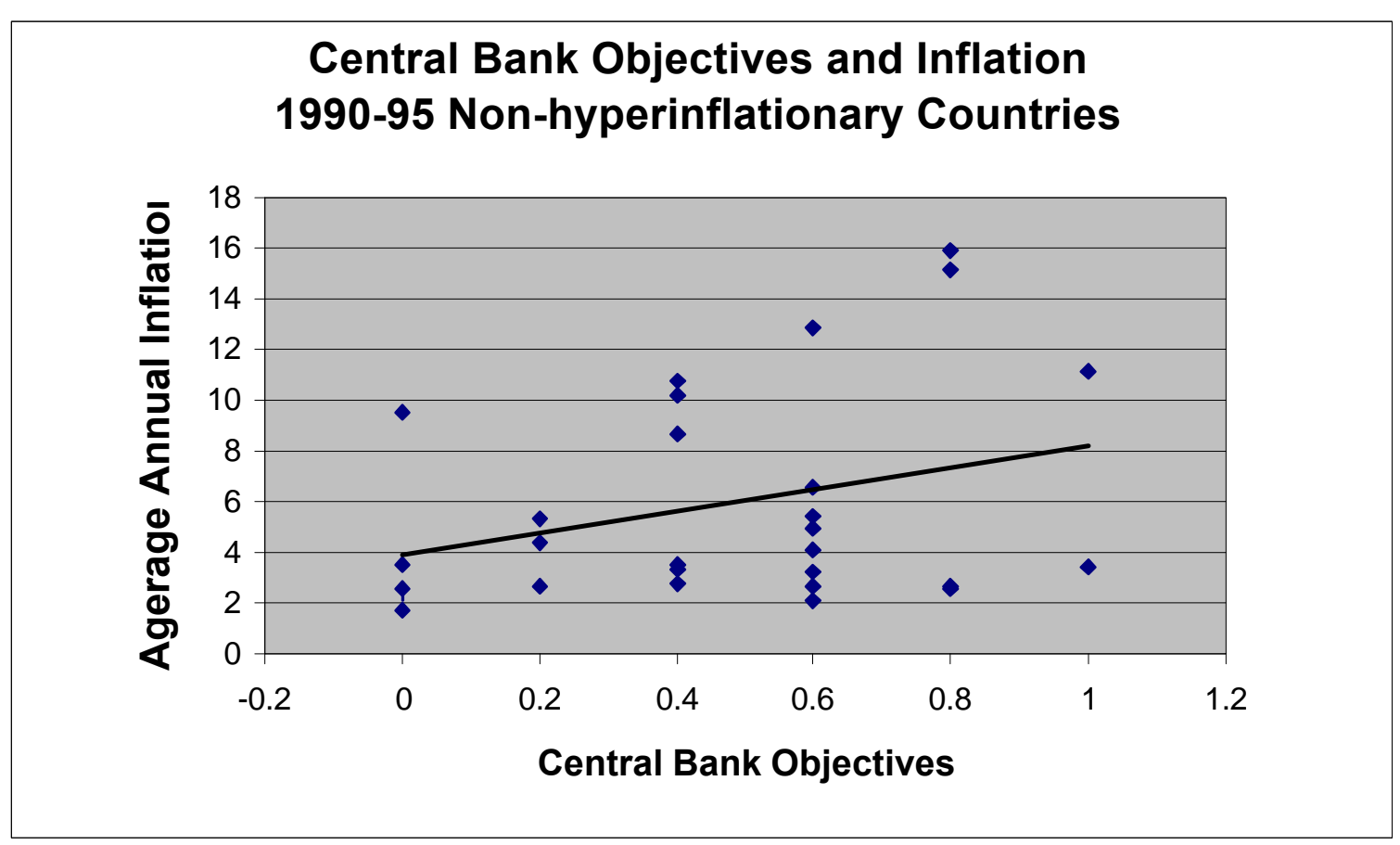

$$
\begin{aligned}
& y=4.3088 x+3.8638 \\
& R 2=0.0982
\end{aligned}
$$

Source: International Monetary Fund, International Financial Statistics; and Cukierman (1992) 